\title{
FOREIGN EXCHANGE RESERVES IN INDIA- A POLICY PERIOD ANALYSIS
}

\author{
Bhakri Suman ${ }^{* 1}$ 雨 (iD), Verma Aman 2 凶 (iD) \\ ${ }^{* 1}$ Associate Professor, Shri Ram College of Commerce, University of Delhi, India \\ 2 Ph.D. Research Scholar, Department of Commerce, Delhi School of Economics, University of Delhi, \\ India
}

DOI: https://doi.org/10.29121/granthaalayah.v8.i11.2020.2454

Article Type: Research Article

Article Citation: Bhakri Suman, and Verma Aman. (2020). FOREIGN EXCHANGE RESERVES IN INDIA- A POLICY PERIOD ANALYSIS. International Journal of Research GRANTHAALAYAH, 8(11), 204-210. https://doi.org/10.29121/granthaa layah.v8.i11.2020.2454

Received Date: 15 November 2020

Accepted Date: 30 November 2020

\section{Keywords:}

Foreign Exchange Reserves (FER)

External Commercial Borrowings

(ECBs)

Liberalization

Globalization

World Recovery

\section{ABSTRACT}

Motivation/Background: Foreign exchange reserves (forex reserves) received large-scale interest among the developing economies because of rapid increase in globalization, the acceleration of capital flows and the integration of capital markets domestically and globally as well. The expansion in the volume of trade activities and capital inflows in the form of investments and external commercial borrowings (ECBs) has led to the emergence of importance of managing the foreign exchange reserves. Foreign exchange reserves (FER) are regulated and managed by the various countries' central banks.

Method: The study is divided into four policy periods, namely, Liberalization, Globalization, World Recovery and Global financial crises. It will be using semi log growth equation model with dummy variables to find out the growth rates in foreign exchange reserves for different policy periods. Trends in foreign exchange reserves have been analysed for the period 1991-2017.

Results: The finding of the study presents that the level of foreign exchange reserves are statistically significant in all the policy periods except world recovery, and the growth rates are also significant in all the policy periods.

Conclusion: The current paper can be of great use for the policy makers as it will help them to analyse the trends in foreign exchange reserves in India not only during various policy periods but also in predicting the future trends of the foreign exchange reserves.

\section{INTRODUCTION}

Foreign exchange reserves (forex reserves) received large-scale interest among the developing economies because of rapid increase in globalization, the acceleration of capital flows and the integration of capital markets domestically and globally as well. This has also posed various challenges to emerging market economies. The debt crises in some developing economies in the nineties have posed several issues and dilemmas to the policy makers on foreign exchange reserves. The policy makers and academicians have started paying considerable attention towards foreign exchange reserves management.

The expansion in the volume of activities related to trade and inflow of capital in the form of investments and commercial borrowing has led to the emergence of importance of managing the foreign exchange reserves. Globally

(C) 2020 The Author(s). This is an open access article distributed under the terms of the Creative Commons Attribution License, which permits unrestricted use, distribution, and reproduction in any medium, provided the original author and source are credited. 
there is no unique definition of foreign exchange reserves because there have been a lot of divergence of views in terms of ownership of assets, liquidity aspects, coverage of items and need for a distinction between owned and nonowned reserves. However, for operational purposes, most countries in the world have adopted the definition suggested by International Monetary Fund (Balance of Payments Manual, and Guidelines on Foreign Exchange Reserve Management, 2001), which defines reserves as "external assets that are readily available to and controlled by monetary authorities for direct financing of external payments imbalances, for indirectly regulating the magnitudes of such imbalances through intervention in exchange markets to affect the currency exchange rate, and/or for other purposes." Reserves are held in one or more currencies, mostly in dollar (US\$) and to a less extent in European Union's euro, the British pound sterling and the Japanese yen.

Foreign exchange reserves are classified into two inter-linked areas, namely, the theory of reserves, and the management of reserves. The theory of reserves encompasses issues relating to legal and institutional arrangements for holding reserve assets, definitional and conceptual aspects, and objectives for holding foreign reserve assets, exchange rate, and determining the appropriate level of foreign reserves. In essence, a theoretical framework for reserves provides the basis for holding forex reserves.

On the other hand, reserve management mainly involves the portfolio management of foreign reserves i.e., how best to deploy foreign reserve assets. The portfolio considerations take into account inter alia, liquidity, safety and yield on reserves as the major objectives of reserve management. Foreign exchange reserves are called reserve assets in the balance of payments and are recorded in the capital account. The reserves are regarded as assets under functional category. In terms of financial assets classification, the reserve assets are classified as gold bullion, unallocated gold accounts, currency, special drawing rights, reserve position in the IMF, interbank position, other deposits, other transferable deposits, debt securities, loans, equity (listed and unlisted), financial derivatives, such as forward contracts and options and investment fund shares. There is no corresponding item for reserve assets in liabilities of the international investment position. Usually, when the monetary authority of a country has some kind of liability, this will be included in other categories, such as other investments. In the Central Bank's Balance Sheet, foreign exchange reserves are assets, along with domestic credit.

The standard approach of measuring foreign exchange reserves takes into account the unencumbered foreign reserve assets held by the respective monetary authorities, however, the foreign currency and securities held by the general public, corporate bodies and the banks are not accounted for in the definition of official holdings of reserves. In India, the Reserve Bank of India Act 1934 contains the provisions for the RBI to act as the custodian of foreign reserves and manage them with the defined objectives. The term 'reserves' refer to both foreign securities held by the Issue Department and foreign reserves held in the form gold assets in the Banking Department and domestic reserves in the form of bank reserves. It is the RBI, as custodian of forex reserves lays down the rules and norms regarding such reserves.

The traditional approaches to reserve determination are considered to be pure trade based models comprising mainly measures of import cover, opportunity cost and foreign exchange market intervention. The approach of India for reserve management, until the balance of payments crisis of 1991 was essentially based on this traditional approach, i.e., to maintain an adequate level of import cover defined in terms of number of months of imports equivalent to reserves. The approach to reserve management underwent a paradigm shift when other areas were also noticed and the need for short term debt discharging and medium term debt servicing was felt.

Unlikely, the contemporary reserve demand models incorporate features like free capital mobility, inflation targeting, return-risk trade-off and complications arising from intermediate exchange rate regimes. Earlier studies on optimum reserves mainly identify three primary motives for accumulating reserves, namely, transaction motive, precautionary motive and speculative motive (Reddy, 2002). While transaction motive applies to reserve demand by the commercial banks, precautionary motive dominates the central bank reserve accumulation behaviour. Besides keeping reserves for meeting the balance of payments deficits, countries also keep certain amount of reserves for meeting unforeseen contingencies.

While considering the management of reserves, the costs and benefits associated with holding reserves should constantly be assessed. On the risks and costs side, maintaining high level of foreign reserves to tide over external shocks involves opportunity costs. It is basically the foregone investment because the resources have been used to purchase foreign exchange reserves instead of increasing domestic capital.

On the benefits side, during financial crises, it has been seen that maintaining and holding sufficient reserves and disclosing adequate information to markets helps a country to prevent itself from external crises, especially those stemming from the capital account, mainly financial institutional investments and external commercial 
borrowings. The reserve management plays a central role because of its growing importance of reserves in crises prevention and as a buffer to manage exchange market pressures. Therefore, we can say that opportunity cost of holding reserves is the marginal productivity of domestic capital and the reserve management authority seeks to minimize this opportunity costs against the benefits that accrue from holding reserves.

Mohanty and Turner (2006) noted that effective sterilization can bring fine results to a country. Green and Toregerson (2007) proposed that sterilization basically neutralizes the inflationary monetary impact of reserve accumulation by offsetting the corresponding increase in money supply with a domestic money market operation, typically domestic debt issuance. However, Mohanty and Turner (2006) emphasized ineffective sterilization may obstruct the growth of the economy and may also bring macroeconomic instability. Sen (2005) noted that RBI intervention to keep the real effective exchange rate (REER) constant, especially in the initial stages of the inflows when it was viewed as temporary. The purchase of foreign exchange reserves raises the monetary base but RBI neutralizes (sterilizes) through a contractionary open market operations, i.e., via the sale of government bonds.

According to Sahu (2015), India maintained the import coverage ratio, which far exceeded the global benchmark of 3 months. The commonly accepted ratio for covering short term external debt is 1 and in India, it was found that this ratio has always been more than 1. India's forex reserves have always been sufficient during his period of study. India not only covered its $100 \%$ short term external debt, but also more than $50 \%$ of total external debt (TED) as against globally accepted norm of at least 40\% coverage.Kapteyn (2001) noted that India maintains market determined exchange rate system and its ratio of foreign exchange reserves to broad money (M2) has always been more than 10 percent. Polterovich and Popov (2003) stated that the accumulation of foreign exchange reserves (FER) contributes to the economic growth of a developing country by increasing both the Investment/GDP ratio and capital productivity.

\section{MATERIALS AND METHODS}

The paper has used annual time series data for the period of 1991-2017 for foreign exchange reserves in India. Data in this study has been extensively used from secondary sources. All the figures that are used in this study are collected from the national and international publications. The time period for the study has been divided into four big policy periods or major changes in Indian economy namely, Liberalization, Globalization, World recovery and Global financial crises. This has been done to analyseand understand the impact of policy periods on the growth of foreign exchange reserves in India.

- Liberalization

- Globalization

- World recovery

- Global financial crises

\begin{tabular}{|c|c|c|}
\hline $1991-92$ to $1994-95$ & - & Policy period I \\
\hline $1995-96$ to $2001-02$ & 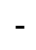 & Policy period II \\
\hline $2002-03$ to $2007-08$ & 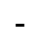 & Policy period III \\
\hline $2008-09$ to $2016-17$ & - & Policy period IV \\
\hline
\end{tabular}

A regression and graphical analysis are undertaken to determine the growth rates of foreign exchange reserves during the period under consideration. Dummy variables have been incorporated in semi log regression model for finding the impact of policy periods on foreign exchange reserves in India. Dummy variable takes the value of 0 and 1.

\section{Semi log Equation with Dummy Variables (Policy Period Analysis)}

Following is the regression equation for policy period analysis in which dummies have been incorporated.

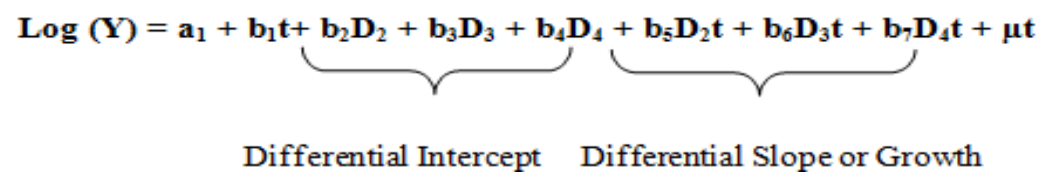

$\log (\mathrm{Y})$ - Natural log of dependent variable, foreign exchange reserves $\mathrm{a}_{1}$ - intercept of policy period I

International Journal of Research -GRANTHAALAYAH 
$b_{1}$ - slope or growth rate of policy period I

$b_{2}$ - difference in intercept of policy period I and II

$b_{3}$ - difference in intercept of policy period I and III

$\mathrm{b}_{4}$ - difference in intercept of policy period I and IV

$b_{5}$ - difference in slope or growth rate of policy period I and II

$b_{6}$ - difference in slope or growth rate of policy period I and III

$b_{7}$ - difference in slope or growth rate of policy period I and IV

$\mu \mathrm{t}$ - error term

\section{Incorporation of Dummies in Regression Equation}

$\mathrm{D}_{2^{-}} \quad 0$ for 1991-92 to 1994-95

1 for $1995-96$ to $2001-02$

0 for 2002-03 to 2007-08

0 for $2008-09$ to $2015-16$

$\mathrm{D}_{3^{-}} \quad 0$ for $1991-92$ to $1994-95$

0 for $1995-96$ to $2001-02$

1 for 2002-03 to 2007-08

0 for 2008-09 to 2015-16

$\mathrm{D}_{4^{-}} \quad 0$ for $1991-92$ to $1994-95$

0 for 1995-96 to 2001-02

0 for 2002-03 to 2007-08

1 for 2008-09 to 2015-16

By using above regression equations for different policy periods, growth rates and intercepts can be computed. These are as follows:

$\begin{array}{lll}\begin{array}{l}\text { For Intercept } \\ \text { Policy period I }\end{array} & - & \\ \text { Policy period II } & - & \mathrm{a}_{1} \\ \text { Policy period III } & - & \mathrm{a}_{1}+\mathrm{b}_{2} \\ \text { Policy period IV } & - & \mathrm{a}_{1}+\mathrm{b}_{3} \\ & & \\ \text { For Slope } & & \\ \text { Policy period I } & - & \mathrm{b}_{4} \\ \text { Policy period II } & - & \mathrm{b}_{1}+\mathrm{b}_{5} \\ \text { Policy period III } & - & \mathrm{b}_{1}+\mathrm{b}_{6} \\ \text { Policy period IV } & - & \mathrm{b}_{1}+\mathrm{b}_{7}\end{array}$

\section{Hypotheses}

There are hypotheses which have been tested at $5 \%$ level of significance and the null hypotheses are as follows:

$\mathrm{H} 1_{0}$ : There is no difference in the level of foreign exchange reserves between the period of liberalization and globalization

$\mathrm{H} 2_{0}$ : There is no difference in the level of foreign exchange reserves between the period of liberalization and world recovery

$\mathrm{H}_{3}$ : There is no difference in the level of foreign exchange reserves between the period of liberalization and global financial crises

$\mathrm{H} 4_{0}$ : There is no growth in the value of foreign exchange reserves during the period of liberalization

$\mathrm{H}_{5}$ : There is no growth in the value of foreign exchange reserves during the period of liberalization and globalization

$\mathrm{H6}_{0}$ : There is no growth in the value of foreign exchange reserves during the period of liberalization and world recovery

$\mathrm{H} 7_{0}$ : There is no growth in the value of foreign exchange reserves during the period of liberalization and global financial crises 


\section{RESULTS AND DISCUSSIONS}

The regression statistics, for the growth of different policy periods, explains significant or insignificant levels of different growth rates of foreign exchange reserves in India for different policy periods (Table 1 and Table 2).

Table 1: Regression Statistics of Foreign exchange reserves in India

\begin{tabular}{|l|l|l|l|l|}
\hline & Coefficients & Standard Error & $t$ Stat & P-value \\
\hline Intercept & 8.303286254 & 0.12261127 & 67.72041619 & $4.02803 \mathrm{E}-24$ \\
\hline Time & 0.364631521 & 0.044771306 & 8.144312876 & $1.2838 \mathrm{E}-07$ \\
\hline D2 & 1.183317379 & 0.198427604 & 5.963471579 & $9.70401 \mathrm{E}-06$ \\
\hline D2T & -0.26161416 & 0.048604638 & -5.382493634 & $3.40786 \mathrm{E}-05$ \\
\hline D3 & -0.32559312 & 0.370290805 & -0.879290332 & 0.390229351 \\
\hline D3T & -0.11292595 & 0.050765889 & -2.224445528 & 0.038435206 \\
\hline D4 & 3.642281105 & 0.278453833 & 13.08037699 & $5.96154 \mathrm{E}-11$ \\
\hline D4T & -0.33373646 & 0.046108056 & -7.238137726 & $7.16777 \mathrm{E}-07$ \\
\hline
\end{tabular}

Table 2: Growth rate of Foreign exchange reserves for different policy periods

\begin{tabular}{|l|l|l|l|}
\hline Policy Period & Intercept & ACGR (\%) & About Growth Rate \\
\hline Liberalization & 8.303286254 & 43.99833074 & Significant \\
\hline Globalization & 9.486603633 & 10.85106592 & Significant \\
\hline World recovery & 8.303286254 & 28.62172766 & Significant \\
\hline Global Financial Crises & 11.94556736 & 3.137726701 & Significant \\
\hline
\end{tabular}

The findings of the study clearly indicates that during the period of liberalization, the initial level of foreign exchange reserves of India was positive and it grew at 43.99\%, which is statistically significant also, as P-value is less than 0.05 (5\%). During the period of globalization, the level of foreign exchange reserves increased in comparison to liberalization, but the growth rate decreased drastically from $43.99 \%$ to $10.85 \%$. This is a situation of "euphoria". Both the level of foreign exchange reserves and the growth rate are statistically significant. This means that globalization had a significant impact on the foreign exchange reserves of India. As far as the period of world recovery is concerned, it is observed that the level of foreign exchange reserves has not changed as compared to liberalization, as the value of D3 is not statistically significant. But the growth rate has decreased to $28.62 \%$ as compared to liberalization, which is statistically significant also. This implies that world recovery period had a significant impact on the growth rate of foreign exchange reserves in India.

The period of global financial crises witnessed large amount of increase in the level of foreign exchange reserves in India in comparison to liberalization (intercept D4) and it is statistically significant also, but the growth rate has decreased drastically as compared to liberalization. This was mainly due to the outward flow of funds from India. India was less affected from the crises, as compared to other countries, due to increased level of foreign exchange reserves during the period of crises as compared to liberalization.

\section{Growth Curve of Foreign exchange reserves}
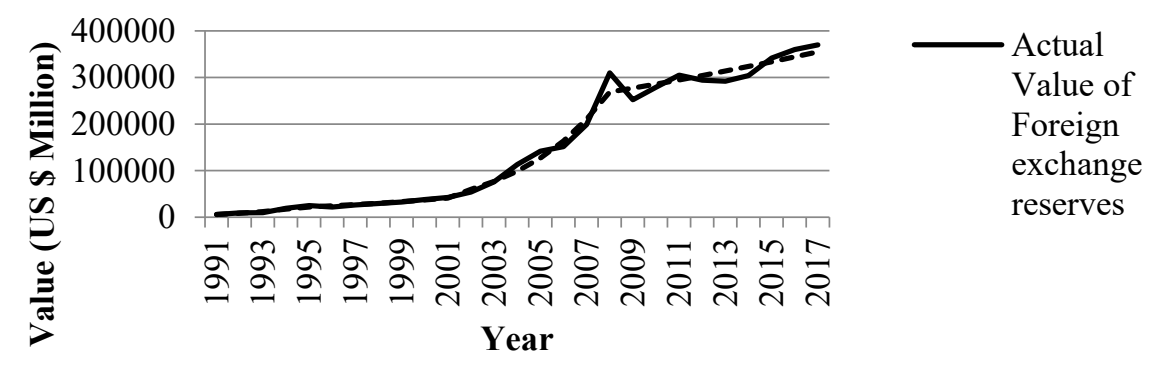

Figure 1: Growth curve of Foreign exchange reserves for different policy periods 
The growth curve clearly indicates that during the entire period of study (1991-2017), there was significant growth in the value of foreign exchange reserves in India. The figure 1 basically shows the upward trend in the differential growth of foreign exchange reserves between liberalization and other policy periods. During liberalization, there was growth in the value of foreign exchange reserves. As far as the globalization period is concerned, there was again significant growth in the value of foreign exchange reserves. This was mainly due to increasing FDI inflows into India. The value of foreign exchange reserves declined during the period 2007-2009, due to global financial crises as can be seen in the figure 1. One of the reasons identified for decline in foreign exchange reserves during the above said period was outflow of FDIs and FIIs from India. Still, India was less affected from the global financial crises and soon observed rise in the foreign exchange reserves. India witnessed an upward trend in foreign exchange reserves 2009 and thereafter.

\section{CONCLUSION AND RECOMMENDATION}

The paper hasanalysed the impact of different policy periods on trends in foreign exchange reserves in India. The study has rejected six hypotheses out of a total of 7 hypotheses. The hypotheses $\mathrm{H} 2_{0}$, is not rejected, because its P-value is not coming out to be significant. The four policy periods, i.e., Liberalization, Globalization, World Recovery and Global Financial Crises are being considered for the analysis.

The above analysis conclude that the level of foreign exchange reserves are statistically significant in all the policy periods except world recovery, and the growth rates are also significant in all the policy periods. The current paper can be of great use for the policy makers as it will help them to analyse the trends in foreign exchange reserves in India not only during various policy periods but also in predicting the future trends of the foreign exchange reserves.

The present study has mainly concentrated on the trends in foreign exchange reserves during various policy periods. However, there are various factors like exports, FDIs, FIIs, ECBs, debt repayment etc. which also influence the level of foreign exchange reserves. Further researches can be undertaken in examining the impact of these factors influencing the level of foreign exchange reserves in India. Though the current paper has focussed only on one country (India) leaving the scope for further research by doing comparative analysis for other emerging economies.

\section{SOURCES OF FUNDING}

This research received no specific grant from any funding agency in the public, commercial, or not-for-profit sectors.

\section{CONFLICT OF INTEREST}

The author have declared that no competing interests exist.

\section{ACKNOWLEDGMENT}

None.

\section{REFERENCES}

[1] Barnichon, R. (2008). International Reserves and Self Insurance against External Shocks. Washington, DC: International Monetary Fund.

[2] Chowdhury, F. (2015). Prospects of Foreign Exchange Reserves- A Study on Bangladesh. DIU Journal of Business and Economics, 9(1), 77-90.

[3] Chowdhury, M., Uddin, M., Islam, M. (2014). An econometric analysis of the determinants of foreign exchange reserves in Bangladesh. Journal of World Economic Research, 3 (6), 72-82.

[4] Dabla-Norris, E., Kim, J., Shirono, K. (2011). Optimal Precautionary Reserves for Low-Income Countries: A Cost-Benefit Analysis. Washington DC: International Monetary Fund. 
[5] Dooley, M., Lizondu, J., Matheison, D. (1989). The currency composition of foreign exchange reserves. IMF Staff Papers, 36(2), 385-434.

[6] Green, R., Tom, T. (2007). Are high foreign exchange reserves in emerging markets a blessing or a burden? Occasional paper no. 6, Department of the treasury, Office of International affairs.

[7] Hatase, M., Mari, O. (2009). Did the structure of trade and foreign debt affect reserve currency composition? Evidence from interwar Japan European Review of Economic History, 13 (3), 319-347.

[8] Hayashi, F., Sims, C. (1983). Nearly Efficient Estimation of Time Series Models with Predetermined, but not Exogenous, Instruments. The Econometric Society, 51(3), 783-798.

[9] International Monetary Fund, International Financial Statistics, IMF Data, website of IMF.Accessed June 2017.

[10] Islam, M.S. (2009). An Economic Analysis of Bangladesh's Foreign Exchange Reserves. SAS Working Paper 85.

[11] Krušković, B., Maričić, T. (2015). Empirical Analysis of the Impact of Foreign Exchange Reserves to Economic Growth in Emerging Economies. Applied Economics and Finance, 2(1), 102-108.

[12] Mohanty, M., Philip, T. (2006). Foreign exchange reserve accumulation in emerging markets: what are the domestic implications? 'SSRN-id1632410'. Bank for International Settlements, 39-52.

[13] Moore, W., Glean, A. (2016). Foreign exchange reserve adequacy and exogenous shocks. Applied Economics, 48(6), 490-501.

[14] Ozyildirim, S., Yaman, B. (2005). Optimal versus Adequate Level of International Reserves: Evidence for Turkey. Applied Economics, 37(13), 1557-1569.

[15] Polterovich, V., Victor, P. (2003). Accumulation of foreign exchange reserves and long term growth. SSRNid1751866.

[16] Ray, S. (2012). Foreign Exchange Reserve and its Impact on Stock Market Capitalization: Evidence from India. Research on Humanities and Social Sciences, 2 (2), 46-61.

[17] Reddy, Y. (2002). India's foreign exchange reserves- policy, status and issues. Economic and Political Weekly, 37 (20), 1906-1914.

[18] Reserve Bank of India, Database on Indian Economy, Statistics, website of RBI. Accessed June 2017.

[19] Sahu, S. (2015). Adequacy of India's Foreign Exchange Reserves. The Clearing Corporation of India Limited, Monthly Newsletter.

[20] Sen, P. (2005). India's foreign exchange reserves: An embarrasement of riches. Economic and political weekly, 40(20), 2018-2019.

[21] Shrestha, P. (2016). Macroeconomic Impact of International Reseves: Empirical Evidence from South Asia. NRB Working Paper No. 32.

[22] Singh, C. (2005). Should India use Foreign Exchange Reserves for Financing Infrastructure? Stanford Center for International Development, Working Paper No. 256.

[23] World Bank, World Bank Data Bank, website of World Bank. Accessed June 2017.

[24] Worrel, D. (1976). The theory of optimal foreign exchange reserves in a developing country. Sir Arthur Lewis Institute of Social and Economic Studies, University of the West Indies, 25(3), 259-279. 